\title{
Natural history of cyanotic malformations and comparison of all common cardiac malformations
}

\author{
Maurice Campbell \\ From Guy's Hospital and the Institute of Cardiology, London
}

At birth, cyanotic malformations are about 20 per cent of all cardiac malformations. But only Fallot's tetralogy and transposition of the great arteries reach an incidence of the same order as several acyanotic malformations.

In children at hospital clinics, only Fallot's tetralogy retains a similar position. The mortality of all cardiac malformations in the first year of life is very high, but for truncus arteriosus and transposition it is so high that at clinics for older children and adults few examples of the former are seen, and the latter has sunk to a small percentage, only of the same order as pulmonary and tricuspid atresia.

An excellent American study of the natural history of transposition of the great arteries gives - the mean age of death as Io months, hardly a month for those without a septal defect, but 22 months for those with a ventricular septal defect also. The few with both ventricular septal defect and pulmonary stenosis had an expectation of life of nearly 5 years.

For Fallot's tetralogy, Abbott (1936) found an expectation of I2 years. My first 296 patients had a mean age of 12 years and would certainly have lived some years more. Excluding those dying in their first year, the expectation of life must be nearer 15 years.

For truncus arteriosus and for pulmonary and tricuspid atresia, I have no evidence for changing Abbott's mean age of death of 4 or 5 years. But the deaths are not symmetrically distributed about these means, the younger ones being concentrated in the early years and the older ones spread over a wide period to the twenties or sometimes the thirties. Patients illustrating this are mentioned. 'Some special feature, such as an unusual capacity for increasing pulmonary blood flow through bronchial arteries, is often responsible for their better outlook.

Finally, a comparison of all the common cardiac malformations is made. The numbers dying in each decade are shown in a Figure and the mean age of death in Table 2.

The incidence of the commoner cyanotic mal-

- formations is shown in Table $I$, at birth from Campbell (1968c) and for her 1000 necropsies

' from Abbott (1936). Transposition of the - great arteries $(8 \%)$ is the most common, then Fallot's tetralogy (6-9\%), pulmonary atresia . $(3 \%)$, truncus arteriosus $(2-3 \%)$, and tricuspid atresia ( $1 \%)$. The figures for pulmonary

' atresia are less certain because in some ، series used for this estimate cases with a ven-

- tricular septal defect were included with Fallot's tetralogy.

It seems worth writing something about their natural history to complete the series (Campbell, I968a, b, I969, I970a, b, I97I). , The malformations will be discussed mainly in the above order.

The mortality in the first year of life is very

Received I7 March 197 I. high in nearly all cardiac malformations. For transposition and truncus arteriosus it is about 90 per cent, so high that their incidence in children at paediatric clinics is quite different. Here the percentages are Fallot's tetralogy (I I \% of all cardiac malformations), transposition $(4 \%)$, pulmonary and tricuspid atresia (each $\mathrm{r} \cdot 5 \%$ ), and truncus arteriosus (0.5\%). In older children and in my own experience Fallot's tetralogy is even more common ( $14 \%)$, but such patients were specially likely to attend my clinic because of the widespread interest in its surgical treatment in 1947-56.

\section{Transposition of great arterial trunks}

The outlook for patients with transpositions has long been recognized as very poor. Abbott (1936) found the mean age of death at her 49 necropsies to be only $\mathrm{I} \cdot 4$ years, and this 
was too high. She found it to be 3 years for the 17 with a ventricular septal defect, but only 6 months for the 32 others.

Liebman, Cullum, and Belloc (1969) have produced the most complete account I know of the natural history of any cardiac malformation. Of their 655 collected and personal infants with transposition, over half died in their first month and 89 per cent in their first year (Table 2). Another 7 per cent died before they were 5 years old and 2 per cent more before they were Io, making 98.6 per cent in the first decade. Another $\mathrm{I} \cdot 2$ per cent died during the second decade, leaving only 2 in each 1000 alive at 20 years. The mean age of death was only Io months. Naturally, with these short lives the study of the natural history was less difficult than for most cardiac malformations.

Nearly half the infants had no septal defect and their expectation of life was hardly a month. For those with an atrial septal defect it was 9 months, and for those with a ventricular septal defect 22 months. For the few (6\%) with a ventricular septal defect and pulmonary stenosis it was increased to nearly $5(4.85)$ years.

For most cardiac malformations the expectation of life has been considered for those who have survived the hazards of the first year of life. If this is applied to their infants, they found it nearly 4 years, and for those with a ventricular septal defect 5 years.

My 1946-56 experience proves only that children already surviving some years have a better outlook. Campbell and Suzman (I95I) described 8 patients with transposition aged between 2 and 13 (mean 7) years, and 2 who had also infundibular stenosis aged 3 and 24 years. They were not doing very well and with their large hearts were not likely to live many more years. They were presumably the lucky survivors of about 350 infants with transposition. Among the 8 necropsies of my patients, the mean age of death was only 7 years.

\section{Fallot's tetralogy}

This is the commonest cyanotic condition after infancy and one for which we have personal evidence about its later history. The age incidence, percentages by decades, for 296 patients seen at my clinics is shown in Table 3, and they have a mean age of 12.3 years. In general, this is not a method that can be used for estimating the mean age of death because the patients are overweighted with children brought by their parents or sent from school clinics.

But for Fallot's tetralogy I think it is more
TABLE I Incidence of cyanotic cardiac malformations at birth and at necropsies with mean ages

\begin{tabular}{|c|c|c|c|}
\hline \multirow[t]{2}{*}{ Malformation } & \multirow{2}{*}{$\begin{array}{l}\text { Incidence at } \\
\text { birth }^{\star} \\
\text { (Campbell, I968c) }\end{array}$} & \multicolumn{2}{|c|}{$\begin{array}{l}\text { Among Abbott's (I936) } \\
\text { IOoo necropsies }\end{array}$} \\
\hline & & Incidence ${ }^{\star}$ & Mean age $(y r)$ \\
\hline Transposition of great arteries & 8 & $8 \cdot 1$ & $6 / 12-2$ \\
\hline Fallot's tetralogy & 6 & $8 \cdot 5$ & 12 \\
\hline Truncus arteriosus & $2 \cdot 7$ & $2 \cdot I$ & 4 \\
\hline Pulmonary atresia & $3 t$ & $3 \cdot 0$ & 5 \\
\hline Tricuspid atresia & I & $I \cdot 6$ & 5 \\
\hline
\end{tabular}

* Incidence is shown as a percentage of all cardiac malformations. + This figure is less reliable because pulmonary atresia is classified differently in + some series used.

accurate because nearly all adult subjects were sufficiently disabled to come to hospital with the hope of improvement by operation. Abbott (1936) gave the mean age of death for her 85 necropsies as 12 years. Obviously my patients still had some years to add to their 12.3 years, and I think the true length of life is probably nearer 15 years. Of my 58 patients whose age of death was known, the mean was just under 9 years (Table 4), but this takes no account of the much larger number who had been operated on. I cannot apply the methods used for other malformations because so many had operations almost at once and so much of my time was needed for following these patients.

The length of life of patients who have had operations has, of course, no significance for the natural history, but 80 per cent of them were still leading a satisfactory if quiet life with a mean age that was already 17 years (Campbell, 1958). Assuming relapses and deaths continued at similar rates, half would still be well 15 years later with a mean age of 32 and several should live at least till their 40 's.

TABLE 2 Age at death of 655 patients with transposition of great trunks (\%) (from Liebman, Cullum, and Belloc, 1969)

\begin{tabular}{lclc}
\hline Age & $\begin{array}{l}\text { \% } \\
\text { dying }\end{array}$ & Age & $\begin{array}{c}\% \\
\text { dying }\end{array}$ \\
\hline Ist week & 28.7 & 2nd to 5th years & $7 \cdot 5$ \\
Rest of Ist month & 22.9 & 6th to I0th years & I.8 \\
2nd to 6th months & 33.9 & I rth to 20th years & $1 \cdot 2$ \\
7th to I2th month & 3.8 & After 20 years & 0.2 \\
\hline First year & 89.3 & Total & I00 \\
\hline
\end{tabular}




\section{Truncus arteriosus}

Abbott gave the mean age of death in her 21 necropsies as 4 years. Bruins and Dekker (r968) say that 2 out of 3 patients die within the first 6 months. Campbell and Deuchar (I96I) described 45 cyanotic patients with continuous murmurs. One died, aged 3, after ' angiocardiography and was proved to have truncus arteriosus. Two others with truncus

- but no continuous murmur died aged 4 and 9 respectively. Eighteen of the 45 had pulmon-

- ary atresia and are discussed in the next

- section and Io had various conditions, mostly Fallot's tetralogy, or were completely un, diagnosed.

The remaining 16 were classified as having

a a solitary trunk without any decisive evidence whether there was a true truncus or pulmon-

- ary atresia with the aorta carrying blood to the

- lungs as well as to the rest of the body. The

"haemodynamic conditions in these two malformations are almost identical so that a firm diagnosis may be impossible in living patients.

2 Of these 16, only 4 died, aged 16, 19, 19, and 30, respectively. All these 4 were among

- the 7 who had a diminished blood supply to

- the lungs and there were no deaths among the

- 9 with an increased pulmonary flow. These patients were under observation for several years from a mean age of II (generally between 4 and 24) years to one of 19 (generally between 15 and 30 ) years. Most were doing - reasonably well and many of them almost i certainly had truncus arteriosus. Its early mor- tality is so high that Abbott's four years for the mean age of death may not be much too low, but certainly more of these subjects with truncus or pulmonary atresia were still living

- in the second and third decades than among those with transposition.

\section{- Pulmonary atresia}

- Abbott (1936) found the mean age of death

- about 5 years, and that about one-quarter of

- her cases had an intact ventricular septum. In my experience more than three-quarters have

- a ventricular septal defect with a clinical picture like Fallot's tetralogy.

- Some of the I6 patients with a solitary

" trunk just described almost certainly had

- pulmonary atresia. They were under observation and doing fairly well without operation from a mean age of $\mathrm{I}$ I to 19 years, long beyond - the normal age of deaths. Most of my other patients with pulmonary atresia had anasto- motic operations, and they too were beyond , the usual age of death, already with a mean

i age of 9 years (mostly 5 to 12 ). Of these 27 patients, IO $(37 \%)$ died and 7 did not obtain
TABLE 3 Percentage age incidence by

decades for Fallot's tetralogy

\begin{tabular}{lcccccccc}
\hline Decade & $0-9$ & $10-19$ & $20-29$ & $30-39$ & $40-49$ & $50-59$ & $\begin{array}{l}\text { Mean } \\
\text { age } \\
(y r)\end{array}$ & $\begin{array}{l}\text { No. of } \\
\text { patients }\end{array}$ \\
\hline Fallot's tetralogy & 50 & 34 & 12 & 2 & I & I & $12 \cdot 3$ & 296 \\
\hline
\end{tabular}

much benefit, often because the arteries to the lungs were so small that an anastomosis could not be completed or was not effective when it could be (Campbell, 1960).

The remaining Io, however, did very well and maintained their improvement from 6 to I I years later. These two groups, already old for patients with pulmonary atresia when first seen, got on well for about another 8 years (some with and some without operation). Older patients seem to have a better outlook than the average, probably because their circulation is better adapted to the malformation by an unusual capacity for developing larger bronchial arteries. They prove that several subjects with pulmonary atresia live to the third decade or later, but not necessarily that the mean age of death is more than 5 years.

\section{Tricuspid atresia}

This is not very common but forms about $\mathrm{I} \cdot 5$ per cent of all cardiac malformations (Abbott, 1936; Wood, 1956). It formed 5 per cent of my first 670 cyanotic malformations. A diagnosis based on the usual triad, cyanosis, left ventricular preponderance, and a small nonfunctioning right ventricle generally proves correct but includes some others and some with a single ventricle or transposition as well. The general problems were discussed on 40 patients (Campbell, 196I) of whom 6 were proved to have a wrong diagnosis.

The mean age of the 34 with tricuspid atresia was 7.4 years, 26 being in the first decade, 7 in the second, and only 1 aged 23 years. Of the 22 who did not have an operation, 16 died, 14 within 3 years, I after 4 years, and $I$ after 6 years, an exceptionally heavy

TABLE 4 Age at death in Fallot's tetralogy

\begin{tabular}{llllllll}
\hline Age & $1-4$ & $5-9$ & $10-14$ & $15-19$ & IO-24 & $\begin{array}{l}\text { All } \\
\text { ages }\end{array}$ & $\begin{array}{l}\text { Mean age at } \\
\text { death }(y r)\end{array}$ \\
\hline No. of deaths & 16 & 22 & 9 & 5 & 6 & $58^{\star}$ & 8.9 \\
\hline
\end{tabular}

^ Excluding 7 under I year. 
mortality with a mean age of death of only 3 years. Of the remaining 6 , we could not trace 2 , but 4 were getting on well and were under observation from age $I$ to 5 years, from 8 to I9, from 12 to 22 , and from 18 to 24 years. The last 3 had shown their slighter degree of disability by reaching even the age when they were first seen. I feel fairly sure that in most malformations with a low mean age of death those who have passed this age have a better outlook for some time in the future. They are the subjects who for various reasons have a circulation better adapted to the malformations than is usual.

The final 12 who had anastomotic operations were slightly older ( 4 to I9 years, mean 9) than the others with tricuspid atresia. Three died soon after operation, but 9 got on well for a mean that was already 8 years, 7 still living and well and 2 dying after an extra 7 and II years of more active life.

\section{Ebstein's anomaly of tricuspid valve}

This is an uncommon cardiac malformation. Simcha and Bonham-Carter (1971) described 32 patients up to 15 years of age with a good short-term outlook unless they had persistent cyanosis or paroxysmal tachycardia. These two conditions were responsible for the 7 early deaths. Watson (197I) also found a relatively good prognosis in childhood after infancy. He describes the start of a survey of 450 such children by the Association of European Paediatric Cardiologists, so we should learn much more about this in the next few years.

Aortic atresia seems just worth mentioning as an example of an acyanotic malformation, generally fatal in a very short time. Abbott (1936) gave the mean age of death in her 21 necropsies as $\mathbf{2}$ months. More recently, Luna, Santos, and Sznejder (1963) described 8 consecutive cases born in their hospital, all of whom died within 3 days with an average duration of life of only 33 hours.

\section{Comparison of ages of death in com- moner cardiac malformations}

The percentages of subjects dying at different ages from the commoner malformations are shown in the Figure, and the mean age of death in Table 5. The number of deaths expected among normal subjects is shown on the left of the Figure: few die before 50, and nearly half are living at 70 years. Persistent ductus arteriosus comes nearest to this but a long way behind: more than half have died by 50 and only 30 per cent are living at 70 , most of them with their ductus having closed spontaneously.

At the other extreme is transposition of the great arteries where 89 per cent die in their first year. The curve shown for this is not strictly comparable because for other conditions death during the first year is excluded. This, of course, does not affect the fact that hardly any subjects are living at 20 years. Next comes Fallot's tetralogy with nearly 85 per cent dying before 20 and about 4 per cent dying between 30 and 50, or occasionally 60 years.

Large and small ventricular septal defects behave in such different ways that separate curves have been drawn for large ventricular septal defects and for all ventricular septal defects. The last curve is unlike any other. It starts badly with a heavy mortality, but then crosses two other curves and rises steeply like the persistent ductus curve. This leaves 24 per cent living at 70 , all or nearly all of them being subjects where the defect has closed spontaneously.

The other 5 curves are similar in shape from atrial septal defect, the most favourable, through aortic stenosis, aortic coarctation, and pulmonary stenosis, to large ventricular septal defect, the most unfavourable. Atrial septal defect is much the most favourable at 20 years, nearly as good as persistent ductus, but by 40 and onwards it is only a little better than the others. Aortic stenosis also is better at 20 years but loses nearly all its advantage by 30 and after. Aortic coarctation is always a little

TABLE 5 Approximate mean age at death for various cardiac malformations

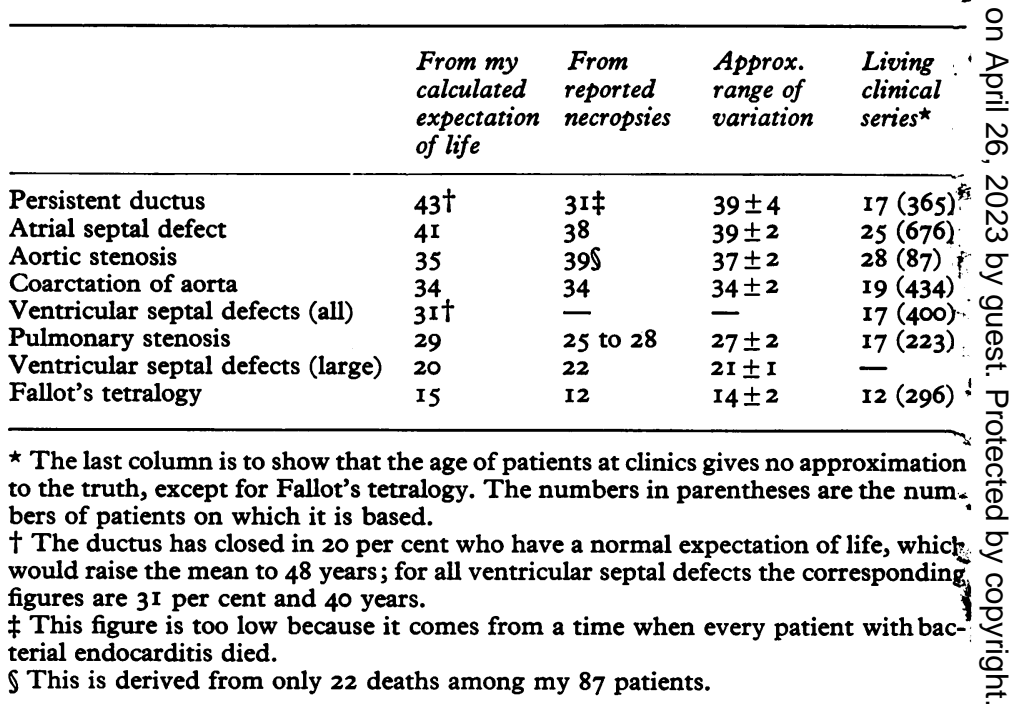


better than pulmonary stenosis and this a little better than large ventricular septal defect. My calculations for pulmonary stenosis may have been too gloomy, but all probably show too many living at 60 and after, though the numbers are not large for any of these five curves.

The approximate mean ages of death in these conditions from my calculations and from reported necropsies are shown in Table .5 and give the same general picture. The mean age falls from 72 in normal subjects to 43 ayears for persistent ductus arteriosus, to $4 \mathrm{I}$ - years for atrial septal defect, to 35 years for -aortic stenosis, to 34 years for aortic coarctation, to 31 years for all ventricular septal defects, to 29 years for pulmonary stenosis, to 20 years for large ventricular septal defect, and to I5 years for Fallot's tetralogy. For - other cyanotic malformations it is much lower, , about 4 or 5 years, and for transposition of the great vessels only Io months. If the 20 to 24 per cent of subjects where a persistent duc'tus or ventricular septal defect has closed spontaneously are included, the mean ages of - death would be raised from 43 to 48 and from 3I to 40 years, respectively.

The last column of Table 5 shows the mean lages of patients seen at hospitals and shows how grossly these would underestimate the - mean age of death, with the exception of Fallot's tetralogy. This no doubt was because older patients with tetralogy were as keen for improvement by surgical treatment as youn"ger ones, while in general the figures are over- weighted by children with few symptoms brought to hospital by their parents or sent from school clinics.

The evidence on which my calculations are - based is not enough to make the figures exact but probably they are correct within \pm 4 per - cent. Thus, no one can doubt the enormous henefits brought to those with cardiac mal- formations by the surgeons who since 1939

' have devised and carried out operations that cure or alleviate these conditions.

Apart from small ventricular septal defects that will probably close spontaneously, and - persistent ducts with evidence of closing, all patients with the commoner cardiac malfor- mations should have operations, though the a best time for these must be settled for each - malformation and for each patient. We may perhaps learn that pressure gradients below - certain levels are not important but this has not been shown and may not be.

The length of life after operation is not, of . course, its natural history but is very important. This has been described shortly for - Fallot's tetralogy. For persistent ductus there is evidence that nearly all do well for several

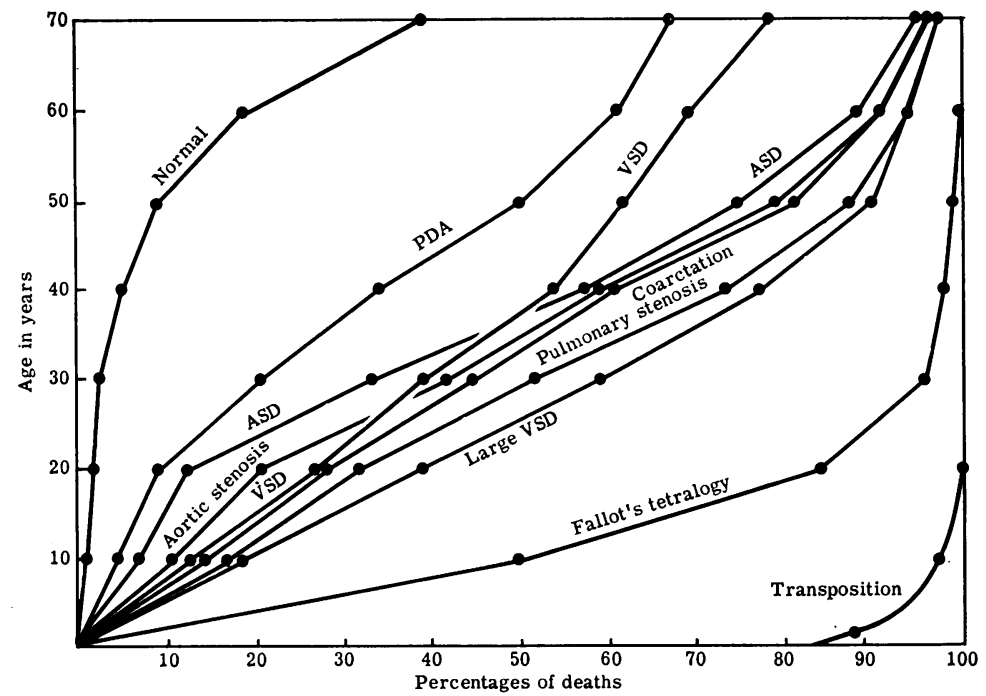

FIG. Percentages of deaths each decade for normal subjects (on left), for subjects with Fallot's tetralogy and transposition (on right), and for commoner cardiac malformations, generally acyanotic at first (in between).

years and good reason to hope that they have been given a normal expectation of life. For atrial septal defect they do well for some years, but much longer follow-ups are needed to confirm my hope that they too have a normal expectation of life. For ventricular septal defects and for Fallot's tetralogy after curative operations, the follow-ups are short and more and longer ones are needed.

The outlook for obstructive lesions after operation is less satisfactory. For aortic coarctation the blood pressure is reduced from about $178 / 105$ to $137 / 83 \mathrm{mmHg}$ and stays so for about six years (Campbell and Baylis, I956), but much longer follow-ups are needed. Many patients still have bicuspid aortic valves, which may lead to aortic stenosis or bacterial endocarditis, and berry aneurysms which may rupture even when the blood pressure has been reduced.

Campbell (1959) wrote that 35 (6r \%) of his patients with pulmonary stenosis operated on by Brock had reached a stage where the operation could be regarded as curative and remained unchanged for about six years. $\mathrm{He}$ hoped that open operations might reach an even higher standard.

Aortic stenosis has proved a more difficult problem, but Baker and Somerville (1964) described the greater success after 1958 when heart-lung bypass allowed the surgeon more 
time for repair. Since then homograft aortic valves (Ross, 1962) have provided another answer, but we cannot yet say what the longterm outlook is after operation.

I am disappointed that I have not seen more papers recently dealing with this important aspect of surgery of the heart but pleased that this aspect for several malformations is to be discussed at the 1971 meeting of the American Academy of Pediatrics.

In writing my last paper I should like to thank Russell, Lord Brock, whose surgical skill attracted so many patients to my clinic and Sir Thomas Holmes Sellors for his frequent help; Paul Wood, Charles Baker, Ralph Kauntze, Dennis Deuchar, Frances Gardner, and Geoffrey Reynolds for so many useful discussions; and many other workers in the Cardiac Department, Guy's Hospital, without whose help I could not have collected the data for continuing my writing so long.

\section{References}

Abbott, Maude (1936). Atlas of Congenital Cardiac Disease. American Heart Association, New York.

Baker, C., and Somerville, Jane (1964). Results of surgical treatment of aortic stenosis. British Medical fournal, r, 197.

Bruins, C., and Dekker, A. (1968). Truncus arteriosus. In Paediatric Cardiology, p. 649. Ed. by Hamish Watson. Lloyd-Luke (Medical Books), London.

Campbell, M. (1958). Late results of operations for Fallot's tetralogy. British Medical fournal, 2, 1175.

Campbell, M. (1959). Valvotomy as a curative operation for simple pulmonary stenosis. British Heart fournal, 21, 4I5.

Campbell, M. (1960). Results of surgical treatment for pulmonary atresia. British Heart fournal, 22, 527.

Campbell, M. (196I). Tricuspid atresia and its prognosis with and without surgical treatment. British Heart fournal, 23, 699.

Campbell, M. (1968a). Natural history of persistent ductus arteriosus. British Heart fournal, 30, 4.
Campbell, M. (1968b). The natural history of congenital aortic stenosis. British Heart fournal, 30, 5 I4.

Campbell, M. (I968c). The incidence and later distribution of malformations of the heart. In Paediatric Cardiology, p. 71. Ed. by Hamish Watson. Lloyd-Luke (Medical Books), London.

Campbell, M. (1969). Natural history of congenital. pulmonary stenosis. Aloisio Condorelli; LXX aetatis annum felicitur conficienti ex omnibus Nationibus Docti Viri Scripta ad Medicinam Pertinentia Honoris Causa Collecta D.D.D., p. 69. Rome.

Campbell, M. (I970a). Natural history of coarctation of the aorta. British Heart fournal, 32, 633.

Campbell, M. (1970b). Natural history of atrial septal defect. British Heart fournal, 32, 820.

Campbell, M. (I97I). Natural history of ventricular septal defect. British Heart fournal, 33, 246.

Campbell, M., and Baylis, J. H. (1956). The course and prognosis of coarctation of the aorta. British Heart Fournal, 18, 475.

Campbell, M., and Deuchar, D. C. (1961). Continuous murmurs in cyanotic congenital heart disease. British Heart fournal, 23, 173.

Campbell, M., and Suzman, S. (I95I). Transposition of the aorta and pulmonary artery. Circulation, 4, 329.

Liebman, J., Cullum, L., and Belloc, N. B. (1969). The natural history of transposition of the great arteries. Circulation, 40, 237.

Luna, R. L., Santos, G. M., and Sznejder, M. A. (1963). Aortic atresia. British Heart fournal, 25, 405 .

Ross, D. N. (1962). Homograft replacement of the aortic valve. Lancet, 2, 487.

Simcha, A., and Bonham-Carter, R. E. (1971). Ebstein's anomaly: clinical study of 32 patients in childhood. British Heart fournal, 33, 46.

Watson, H. (I97I). Natural history of Ebstein's anomaly of the tricuspid valve in childhood and adolescence. In Proceedings of the British Cardiac Society. British Heart fournal, 33, 143.

Wood, P. (1956). Diseases of the Heart and Circulation, and ed. Eyre and Spottiswoode, London.

Requests for reprints to Dr. Maurice Campbell, 47 Arkwright Road, Hampstead, London N.W.3. 